\title{
Ultrapure Dialysate Reduces Dose of Recombinant Human Erythropoietin
}

\author{
H. Schiffl S.M. Lang A. Bergner \\ Medizinische Klinik, Klinikum Innenstadt, Universität München, Deutschland
}

Dear Sir,

The widespread availability of recombinant human erythropoietin (rHU-EPO) is one of the greatest advances in clinical nephrology. Approximately $90-95 \%$ of dialysis patients treated with $\mathrm{rHu}-\mathrm{EPO}$ respond with an improvement in their anemia, but individual doses may vary considerably. The most important factors causing this variation are acute or chronic inflammatory processes which may lead to marked resistance to $\mathrm{rHu}$-EPO. It is a well-known fact that exposure of patient's blood to even mildly contaminated dialysate contributes to the systemic inflammatory syndrome of uremia by induction of cytokine synthesis [1]. However, there are no data indicating whether differences in the microbiological quality of the dialysate may affect the response to $\mathrm{rHu}-$ EPO in patients receiving regular hemodialysis.

The aim of our prospective cross-over investigation was to compare the effect of potentially contaminated, commercial (unfiltered) and online produced, ultrapure dialysate on rHu-EPO doses. Twenty-four stable anuric dialysis patients gave informed consent to participate in the study which was approved by the local ethics committee. They all had normocytic normo-chromic anemia of end-stage renal disease and normal levels of folic acid, vitamin $B_{12}$ and ferritin. None of the patients had acute or chronic infection, inflammatory disease, malignancy or chronic bleeding disorders or used immunosuppressive drugs or angiotensin-converting enzyme inhibitors. Hemodialysis was performed with volumetrically controlled ultrafiltration (MTS 4008, Fresenius, Bad Homburg, Germany) and biocompatible high-flux dialyzers (Polysulfone, F60 Fresenius, Bad Homburg, Germany). The bicarbonate dialysate was either commercial or ultrafiltrated using polysulfone filters. Each treatment session lasted 3-5 h, with blood flow rates between 250 and $350 \mathrm{ml} /$ $\mathrm{min}$, and dialysate flow rates at $500 \mathrm{ml} / \mathrm{min}$. Twelve patients each were randomly assigned to treatment with unfiltered (commercial) dialysate for 3 months and crossed over to ultrafiltrated dialysate for another 3 months or were treated in the reverse order. The microbiological quality of the dialysate was checked monthly. Plasma C-reactive protein (CRP) levels and circulating interleukin- 6 concentrations were measured by highly sensitive enzyme-linked immunosorbent assays.

There were no statistically significant differences in the demographic characteristics or treatment-associated parameters between the 2 study groups at recruitment. Both groups had comparable target hemoglobin concentrations and rHu-EPO doses ( $\beta$-epoietin, Boehringer, Mannheim, Germany) at the start of the study (table 1).

In group I continuation of commercial unfiltered dialysate (median 140, range 60$400 \mathrm{CFU}$ ) did not result in a significant change of hemoglobin levels $(10.2 \pm 0.2 \mathrm{~g} /$ $\mathrm{dl})$, rHu-Epo doses (90 $\pm 50 \mathrm{U} / \mathrm{kg} /$ week $)$ or inflammation as determined by CRP $(1.1 \pm$ $0.2 \mathrm{mg} / \mathrm{ml})$ or plasma IL-6 $(55 \pm 15 \mathrm{pg} / \mathrm{ml})$. The change of the dialysate after 3 months, however, caused a significant reduction in rHu-EPO doses $(60 \pm 31 \mathrm{U} / \mathrm{kg} /$ week, $\mathrm{p}<$ $0.05)$ despite comparable hemoglobin levels $(10.3 \pm 0.3 \mathrm{~g} / \mathrm{dl})$ and furthermore led to a significant fall in CRP $(0.6 \pm 0.2 \mathrm{mg} / \mathrm{dl}, \mathrm{p}<$ $0.05)$ and IL-6 (35 $\pm 10 \mathrm{pg} / \mathrm{ml}, \mathrm{p}<0.05)$.

In group II change of the unfiltered to ultrapure dialysate caused a significant reduction in rHu-EPO doses $(62 \pm 32 \mathrm{U} / \mathrm{kg} /$ week, $\mathrm{p}<0.05)$ despite comparable hemoglobin levels $(10.1 \pm 0.2 \mathrm{~g} / \mathrm{dl})$ and a significant fall in CRP and IL-6 concentrations was observed $(0.7 \pm 0.2 \mathrm{mg} / \mathrm{dl}$ and $38 \pm 14 \mathrm{pg} /$ $\mathrm{dl}, \mathrm{p}<0.05$. Reinstitution of commercial dialysate (median 120, range 40-400 CFU) resulted in increased rHu-EPO doses $(87 \pm$ $45 \mathrm{U} / \mathrm{kg} /$ week) to stabilize hemoglobin concentrations at comparable levels (10.2 \pm $0.3 \mathrm{~g} / \mathrm{dl}$ ) and led to an intensified systemic inflammatory response as marked by rises

\section{KARGER \\ Fax +41613061234 E-Mail karger@karger.ch} www. karger.com (c) 1999 S. Karger AG, Basel

0028-2766/99/0833-0278\$17.50/0

Accessible online at: http://BioMedNet.com/karger

\author{
elmut Schiffl, MD \\ Medizinische Klinik, Klinikum Innenstad \\ Universität München \\ Ziemssenstrasse 1 \\ D-80336 München (Germany)
}


Table 1. Patient characteristics at recruitment (mean \pm SD)

\begin{tabular}{lcc}
\hline & Group I & Group II \\
\hline Number of patients & 12 & 12 \\
Age, years & $58 \pm 14$ & $61 \pm 13$ \\
Gender, male/female & $6 / 6$ & $6 / 6$ \\
Time on dialysis, months & $45 \pm 14$ & $48 \pm 18$ \\
Weight, kg & $72 \pm 16$ & $76 \pm 13$ \\
Parathyroid hormone, pg/ml & $133 \pm 15$ & $121 \pm 36$ \\
Serum aluminium, $\mu \mathrm{g} / \mathrm{l}$ & $20 \pm 15$ & $25 \pm 20$ \\
KT/V urea & $1.3 \pm 0.3$ & $1.4 \pm 0.2$ \\
Hemoglobin, g/dl & $10.2 \pm 0.5$ & $10.1 \pm 0.4$ \\
rHu-EPO, U/kg/week & $92.5 \pm 52.5$ & $85.7 \pm 46.8$ \\
CRP, mg/dl & $1.2 \pm 0.2$ & $1.4 \pm 0.4$ \\
IL-6, pg/ml & $58 \pm 23$ & $52 \pm 18$ \\
\hline
\end{tabular}

Table 2. Effects of commercial vs. ultrapure dialysate on rHu-EPO doses (mean $\pm \mathrm{SD})$

\begin{tabular}{lcc}
\hline & $\begin{array}{l}\text { Commercial } \\
\text { dialysate }\end{array}$ & $\begin{array}{l}\text { Ultrapure } \\
\text { dialysate }\end{array}$ \\
\hline Number of patients & 24 & 24 \\
Hemoglobin, g/dl & $10.2 \pm 0.3$ & $10.2 \pm 0.3$ \\
rHu-EPO, U/kg/week & $87 \pm 44$ & $61 \pm 30^{*}$ \\
\hline
\end{tabular}

$* \mathrm{p}<0.05$ vs. corresponding value of commercial dialysate. in CRP $(1.3 \pm 0.2 \mathrm{mg} / \mathrm{dl})$ and IL-6 (61 \pm $16 \mathrm{pg} / \mathrm{dl}$; table 2).

These data demonstrate that even mildly contaminated commercial bicarbonate dialysate causes chronic inflammation by induction of cytokine synthesis. Use of ultrapure (filtered, pyrogen-free and sterile) dialysate reduced the $\mathrm{rHu}-\mathrm{EPO}$ doses required to maintain hemoglobin levels via a reduction in systemic inflammatory processes (table 2).

The mechanisms underlying the increased need for rHu-Epo doses in patients treated with commercial dialysates may in- clude suppression of endogenous erythropoietin secretion, iron delivery and proliferation of erythrocyte precursors [2]. Recombinant erythropoietin administration provides a number of undisputed benefits to patients undergoing maintenance dialysis, but adds significantly to the costs of hemodialysis treatment. Thus, efforts should be directed at minimizing the dose of $\mathrm{rHu}-\mathrm{EPO}$ to achieve optimal target hemoglobin concentrations. The use of ultrapure bicarbonate dialysate is inexpensive and undoubtedly has clinical implications for the treatment of anemia of chronic renal failure.

\section{References}

1 Schindler R, Lonnemann G, Schäffer J, Shaldon S, Koch K-M, Krautzig S: The effect of ultrafiltrated dialysate on the cellular content of interleukin-a receptor antagonist in patients on chronic hemodialysis. Nephron 1994;68: 229-233.

2 Goicoechea M, Martin J, DeSequera P, Quiroga JA, Ortiz A, Carreno V, Caramelo C: Role of cytokines in the response to erythropoietin in hemodialysis patients. Kidney Int 1998;54: 1337-1343. 